\title{
THE EVALUATION OF ACTIVITY AND STABILITY OF ISOLATED BROMELAIN FROM PINEAPPLE CORES (ANANAS COMOSUS [L.] MERR) AND IN VITRO PENETRATION TEST OF NANOEMULSION TOPICAL BASE
}

\section{AINUR ROHMAH ${ }^{1}$, HEGI ADI PRABOWO ${ }^{1}$, SISWATI SETIASIH ${ }^{1}$, SRI HANDAYANI ${ }^{1}$, MAHDI JUFRI ${ }^{2}$, SUMI HUDIYONO ${ }^{*}$}

1Department of Chemistry, Faculty of Mathematics and Natural Sciences, Universitas Indonesia, Depok 16424, West Java, Indonesia, 2Faculty of Pharmacy, Universitas Indonesia, Depok 16424, West Java, Indonesia

*Email: sumi.hudiyono@sci.ui.ac.id

Received: 10 Apr 2021, Revised and Accepted: 26 Jun 2021

\section{ABSTRACT}

Objective: Oral administration of bromelain as an anti-inflammation therapy still faces several challenges, such as the risk of contact with the gastric fluid and its low absorption rate. Therefore, bromelain isolated from the pineapple core will be formulated as a topical base in a nanoemulsion to increase its stability, activity, and ability to penetrate the skin.

Methods: Bromelain was isolated from pineapple core using ammonium sulfate precipitation and dialysis, and then the isolated fraction was loaded into topical nanoemulsion for subsequent evaluation of its characteristics, stability, enzymatic activity, and for in vitro study of penetration using Franz diffusion cell.

Results: The highest specific activity of bromelain fractions found in ammonium sulfate concentration is around $20-50 \%$. After being dialyzed, the bromelain fraction showed an increase in specific activity 2.78-fold as compared to crude extract. The characteristics of bromelain nanoemulsion showed a globule size of $21.37 \pm 1.8 \mathrm{~nm}$ with a polydispersity index (pdI) $0.323 \pm 0.049$, oil in water (o/w) type, and the type of rheology was plastic flow. The nanoemulsion stability base was observed, and there was no phase separation after centrifugation. Bromelain in nanoemulsion base showed a proteolytic activity of $5.00 \mathrm{U} / \mathrm{ml}$ with a protein content of $154.28 \mathrm{mg} / \mathrm{l}$. In vitro penetration studies using Franz diffusion cell for $8 \mathrm{~h}$ showed isolated bromelain in nanoemulsion base has a total cumulative number value of $1386.94 \mu \mathrm{g} / \mathrm{cm}^{2}$ with penetrated velocity $/$ flux (J) of $45.93 \mu \mathrm{g} / \mathrm{cm}^{2} \mathrm{~h}$.

Conclusion: The results showed promise for bromelain loaded into nanoemulsion as a vehicle for topically administered therapeutic enzymes.

Keywords: Pineapple core, Bromelain, Nanoemulsion, Enzyme activity, Franz diffusion cell

(C) 2021 The Authors. Published by Innovare Academic Sciences Pvt Ltd. This is an open access article under the CCBY license (https://creativecommons.org/licenses/by/4.0/) DOI: https://dx.doi.org/10.22159/ijap.2021v13i5.41769. Journal homepage: https://innovareacademics.in/journals/index.php/ijap

\section{INTRODUCTION}

Non-steroidal anti-inflammatory drugs (NSAIDs) are one of the most widely used prescription drugs around the world. However, this class of drugs has several side effects, mainly on the gastrointestinal tract, including ulcers, bleeding, perforation, and obstruction. This problem triggers the researcher to find a natural active compound as an alternative to anti-inflammatory therapy. Indonesia is the fifth largest producer of pineapple in the world [1], which the amount of pineapple production will also increase the number of its wastes. One of that wastes is the pineapple core, which contains a protein-active substance called bromelain. Bromelain content in the pineapple cores is already known as phytomedicine [2], and the development of bromelain application has been extensively performed in the medical and cosmetic industries. One of the therapeutic effects of bromelain could be a regulator of inflammatory mediators. There is an impact of inflammation mediators such as TNF- $\alpha$ (Tumor Necrosis Factor-alpha) and TGF- $\beta$ (Transforming Growth Factor-Beta) with the transdermal application against wound tissue [3]. Bromelain can reduce TNF- $\alpha$ content in a few hours after the injury [4]. Not only TNF- $\alpha$ is controlled by bromelain, but also bromelain increases the expression of TGF- $\beta$ $[5,6]$. Bromelain can involve in the wound pathway because of the loss of necrotic tissue and its ability to control infection. One expression of the wound is the inhibition of TGF- $\beta$ that resulting in continuous inflammation, and increasing TGF- $\beta$ will reduce the inflammation. However, bromelain orally administered still faces several challenges, such as the risk of contact with the gastric fluid and its low absorption rate. It suggests that bromelain has an opportunity to be an inflammatory treatment by transdermal or topical administration. Bromelain is a protein enzyme within pineapple extract that has a limited ability to penetrate through the stratum corneum because of its high molecular weight molecule and its polar properties. Recently nanoemulsion was developed to enhance the absorption of drugs through the skin, which evaluates using in vitro and in vivo methods [7]. Nanoemulsion is also an effective method for releasing active ingredients in small-sized droplets. Small globule size can prevent base instability, such as creaming, sedimentation, and coalescence. Moreover, nanoemulsion can increase the surface area and enhance the effectiveness of penetration in the stratum corneum of the skin [8]. Nanoemulsion promises to improve bromelain stability [9]. Therefore, in this study, bromelain isolated from the pineapple core will be formulated in a nanoemulsion base and evaluated for its stability, activity, and ability to penetrate the skin by using in vitro method.

\section{MATERIALS AND METHODS}

\section{Materials}

The pineapple was purchased from Induk traditional market in Jakarta. Commercial bromelain and EDTA were bought from SigmaAldrich, virgin coconut oil from Vermindo International. Tocopheryl acetate, ethanol 96\%, aquademin, propylene glycol, methylparaben, and propylparaben were purchased from Brataco, while the other chemicals were purchased from Merck.

\section{Enzyme extraction from pineapple core}

The pineapple cores used as a bromelain source come from Palembang, Indonesia. These cores were crushed using a blender with the addition of a pH buffer of 7.0 under cold conditions until shaped like mush and then filtered using a gauze apparatus. The filtrate solution was centrifuged at $6000 \mathrm{rpm}$ in a temperature condition of $4{ }^{\circ} \mathrm{C}$ for $15 \mathrm{~min}$. The supernatant is a crude enzyme fractionated with ammonium sulfate solution.

Isolation using ammonium sulfate fractionation of bromelain and dialysis

The crude enzymes were further fractioned using ammonium sulfate at different ranges of concentrations $(0 \%-20 \%, 20 \%-50 \%$, and $50 \%-80 \%$ ) for $20 \mathrm{~min}$ under cold conditions. Fractions were stored overnight in the refrigerator and then centrifuged at a temperature 
of $4{ }^{\circ} \mathrm{C}$ under $6000 \mathrm{rpm}$ speed for $15 \mathrm{~min}$. Finally, precipitates were suspended in cold solutions of $0.2 \mathrm{M}$ phosphate buffer at $\mathrm{pH}$ 7.0. The highest activity of ammonium sulfate precipitation fraction was further purified by the dialysis process. The dialysis process used a dialysis tube with a typical molecular weight cutoff of $12-14 \mathrm{kDa}$. The dialysis tube was filled with enzyme solution and then immersed in a cold solution of $0.05 \mathrm{M}$ phosphate buffer $\mathrm{pH}$ 7.0. The dialysis system was constantly stirred in cold conditions using an ice bath. The buffer was changed every $2 \mathrm{~h}$. The dialysis was complete when the buffer solution had an absence of $\mathrm{BaSO}_{4}$ precipitate (qualitative analysis using $5 \% \mathrm{BaCl}_{2}$ in acidic solution) [10].

\section{Protein and enzyme activity evaluation}

Isolated Bromelain. We determined the protein content (mg/l) and proteolytic activity $(\mathrm{U} / \mathrm{ml})$ to determine the specific activity $(\mathrm{U} / \mathrm{mg})$. The Lowry method was applied to determine the protein concentration according to the absorbance at $595 \mathrm{~nm}$. Bovine serum albumin (BSA) was used as a protein standard (range $20-100 \mathrm{mg} / \mathrm{l}$ ) The proteolytic activity of bromelain was performed by the Kunitz method using casein as substrate at $37{ }^{\circ} \mathrm{C}$ for $30 \mathrm{~min}$. The enzyme was inactivated by adding $3 \mathrm{ml}$ of $10 \%$ trichloroacetic acid (TCA). Then, the solution was incubated in an ice water bath for $30 \mathrm{~min}$ and then measured by using a UV-Vis spectrophotometer at $280 \mathrm{~nm}$ [11].

Nanoemulsion bases. Bromelain in nanoemulsion base was diluted in a phosphate buffer (1:10). Proteolytic activity and the content protein were evaluated using Kunitz and Lowry method, respectively.

\section{Preparation of nanoemulsion}

In this research, nanoemulsion was made by the high-energy emulsification method. This method was conducted by mixing the oil phase into the water phase. In this case, the variation of surfactant (Tween 80) concentration was 30, 25, and $15(\% \mathrm{w} / \mathrm{v})$. The water phase consists of a mixture of deionized water and Tween 80 that has been heated to a temperature of $37{ }^{\circ} \mathrm{C}$ and then homogenized with a homogenizer of $3000 \mathrm{rpm}$ for $8 \mathrm{~min}$. The oil phase consists of a mixture of Virgin Coconut Oil (VCO), palm oil, oleic acid (5\% w/v respectively), and vitamin e acetate $(1 \% \mathrm{w} / \mathrm{v})$. The oil phase is added to the water phase and then homogenized. Methylparaben $(0.1 \% \mathrm{w} / \mathrm{v})$ and propylparaben $(0.3 \% \mathrm{w} / \mathrm{v})$ were dissolved in propylene glycol $(5 \% \mathrm{w} / \mathrm{v})$, then added to the mixture of the previous base and homogenized. The last, ethanol $(8 \% \mathrm{w} / \mathrm{v})$, is added slowly. The mixture was homogenized under $3000 \mathrm{rpm}$ speed at room temperature and sonicated for an hour. The most stable formula was chosen as a base for bromelain loading. The loading process into the bases was done using the post-loading method. Around $3 \%(\mathrm{w} / \mathrm{v})$ of bromelain was directly added into the nanoemulsion and stirred for $10 \mathrm{~min}$.

\section{Characterization of nanoemulsion}

Emulsion Type. The test involves sprinkling water-soluble dyes (methylene blue) on the nanoemulsion surface and is followed by observation under an optical microscope using a 1 x 0.7 magnification. The oil in water $(\mathrm{o} / \mathrm{w})$ nanoemulsion will dissolve and diffuse the methylene blue into the whole water region evenly. Meanwhile, in the water and oil (w/o) nanoemulsion, methylene blue will cluster on its surface [1].

\section{Size distribution of globule}

Particle size and the polydispersity index were measured using a particle size analyzer (PSA). About $5 \mu \mathrm{l}$ of the sample was dissolved in $10 \mathrm{ml}$ of aqua deionization and then put into the cuvette. The cuvette was inserted into the sample holder. The device was turned on, and the particle size menu was selected. Then, the sample was measured for 15 min, after which the tool produced the globule size and polydispersity index value. The cuvette must be cleaned and free from fat.

\section{Rheology properties}

Viscosity measurements were carried out by using a Brookfield viscometer. Viscosity values were obtained by changing the rpm to $0.5,2,5,10$, and 20 . Then the reverse value was held from $20,10,5$, 2 , and $0.5 \mathrm{rpm}$. Viscosity values are calculated on the measurements part using one type of spindle and a certain speed. Rheology properties of bases were obtained by making a curve between the shear stress (F/A) and the shear rate (dv/dr). The viscosity observations were made in the first week of nanoemulsion.

\section{Stability test of nanoemulsion}

Physical and chemical stability tests of nanoemulsion were carried out in three tests. The tests consist of temperature storage tests at three different temperatures, a cycling test, and a centrifugation test. The bases were stored at three different temperatures: at low temperature $\left(4{ }^{\circ} \mathrm{C}\right)$, room temperature $\left(28^{\circ} \mathrm{C}\right)$, and high temperature $\left(40^{\circ} \mathrm{C}\right)$. Then, the organoleptic properties of nanoemulsions and the $\mathrm{pH}$ change every two weeks for eight weeks were observed. The cycling test was carried out at extreme temperature alterations $\left(4^{\circ} \mathrm{C}\right.$ to $\left.40^{\circ} \mathrm{C}\right)$ at an interval of $24 \mathrm{~h}$ ( 1 cycle) for six cycles. The centrifugation test was carried out using a centrifuge with a rotation speed of $4000 \mathrm{rpm}$ for five hours. The visual of nanoemulsion before and after the cycling test and centrifugation test was observed.

\section{The skin of the mouse preparation}

The Ethics Committee of the Faculty of Medicine at the University of Indonesia approved the use of animals for the present study (Ethical clearance number: 18-12-1476). The mouse in this research was purchased from the Faculty of Pharmacy, Universitas Indonesia. The skin sample was obtained from the shaved abdomen part, in which the subcutaneous fat layer has been removed. The prepared skin was stored in the refrigerator with a maximum storage time of $24 \mathrm{~h}$. Before use, the skin was hydrated by using receptor compartment fluid (phosphate buffer pH 7.4) for $30 \mathrm{~min}$.

\section{In vitro penetration testing}

The percutaneous permeability of bromelain was determined using a Franz diffusion cell membrane, where the diffusion surface area was $1.77 \mathrm{~cm}^{2}$, and the receptor compartment volume was $13 \mathrm{ml}$. The abdominal skin of a mouse was put between the donor compartment and the receptor compartment, for which the dermal side must be directly in contact with the receptor medium. Then, the skin was hydrated with a phosphate buffer $(\mathrm{pH} 7.4)$ at room temperature for $30 \mathrm{~min}$. After that, the phosphate buffer was inserted in the receptor compartment. The temperature of the water bath solution was maintained at $37 \pm 1.0^{\circ} \mathrm{C}$. Around 2 grams of nanoemulsion were applied to the donor compartment. Then, sampling was held at a time interval $(30,60,90,120,180,240,300,360,420$, and $480 \mathrm{~min})$ from the receptor compartment $( \pm 1 \mathrm{ml})$ using a syringe and then the same amount of fresh phosphate buffer was added to the compartment solution. Determination of protein content from the sampling was carried out using the Bradford method. The absorbance sample was measured at $595 \mathrm{~nm}$. Then, the flux and cumulative amount of the penetrated substance were calculated per area. The cumulative amount of penetrated bromelain per diffusion area $\left(\mu \mathrm{g} / \mathrm{cm}^{2}\right)(\mathrm{Q})$ was expressed as follows:

$$
\mathrm{Q}=\frac{\mathrm{CnV}+\sum_{\mathrm{i}=1}^{\mathrm{n}-1} \mathrm{C} . \mathrm{S}}{\mathrm{A}}
$$

Where $\mathrm{Cn}$ is the penetrated concentration in the minute-n $(\mathrm{mg} / \mathrm{l}), \mathrm{V}$ is the volume of diffusion cell $(13.0 \mathrm{ml}), \sum_{\mathrm{i}=1}^{\mathrm{n}-1} \mathrm{C}$ is the amount of concentration in the previous minute sampling, and $S$ is the sampling volume (ml). The penetration rate per unit of time (flux) (J) $\left(\mu \mathrm{g} / \mathrm{cm}^{2}\right.$. hour $)$ was calculated using the following equation:

$$
\mathrm{J}=\frac{\mathrm{M}}{\mathrm{s} \mathrm{xt}}=\frac{\mathrm{Q}}{\mathrm{t}}
$$

Where $\mathrm{M}$ is the cumulative number of substances through the membrane $(\mu \mathrm{g})$, and $\mathrm{T}$ is the time of sampling (hour).

\section{RESULTS AND DISCUSSION}

\section{Isolation of bromelain enzyme}

The specific activity indicates the purity of an enzyme, which could be obtained by determining the protein content and proteolytic activity. Determination of protein content using the Lowry method, in which $\mathrm{Cu}$ (II)-protein formed and $\mathrm{Cu}$ (II) reduced to $\mathrm{Cu}$ (I) in the alkaline condition. The $\mathrm{Cu}^{+}$reduces the Folin-Ciocalteu reagent containing phosphomolybdate-phosphotungstate. Then, Cu- 
catalyzed oxidation of aromatic groups (amino acid side chains) tyrosine and tryptophan will produce blue complexes compound that measured using a UV-Vis spectrophotometer [10]. Proteolytic activity was determined using the Kunitz method. Proteolytic activity is the ability of an enzyme to hydrolyze or break down the protein substrate in its optimum condition. Enzyme proteolytic activity is revealed in units $/ \mathrm{mg}$. An enzyme unit indicates the amount of enzyme needed to produce $1 \mu \mathrm{g}$ of tyrosine per $\mathrm{ml}$ per minute under the optimum conditions of the experiment or can also be defined as the amount of enzyme required to increase the absorbance to 0.001 per minute of control at the optimum conditions of the experiment [11]. The more tyrosine produced, the higher value of absorbance.

The specific activities of fractions are shown in table 1. The specific activity and purity of the crude bromelain are relatively low because the crude bromelain still contains other dissolved proteins. Therefore, further purification is necessary to increase the purity levels of bromelain. The crude bromelain is further purified by fractionation using ammonium sulfate because precipitation with ammonium sulfate salt has several advantages.

Fractionation using ammonium sulfate is carried out with various saturation concentrations to determine the best concentration range to precipitate the desired bromelain-specific protein. Precipitation in different salt saturations was based on protein size. The smaller the protein size, the more amount the salt needed to precipitate the protein. Previous research reported that the proteins precipitate below $25 \%$ ammonium sulfate saturation, generally in the form of particles and pre-aggregated protein or very high molecular weight proteins [12].

Fraction 2 with an ammonium sulfate salt concentration of $20-50 \%$ was found as the fraction with the highest specific activity (table 1). The salt present in the precipitation process will affect bromelain purity. The bromelain fraction with the best specific activity was dialyzed to eliminate the ammonium sulfate on the protein. The dialysis process is increasing the specific activity of the enzyme fraction.

Table 1: Results of the bromelain isolation process

\begin{tabular}{|c|c|c|c|c|c|}
\hline \multirow[t]{2}{*}{ Fraction } & \multirow{2}{*}{$\begin{array}{l}\text { Volume } \\
\text { (ml) }\end{array}$} & \multicolumn{2}{|l|}{ Total } & \multirow[t]{2}{*}{ Specific activity $(\mathrm{U} / \mathrm{mg})$} & \multirow{2}{*}{$\begin{array}{l}\text { Purification levels } \\
\text { (fold) }\end{array}$} \\
\hline & & Proteolytic activity (U) & Protein content (mg) & & \\
\hline Crude Enzyme & 717 & $7170.00 \pm 878.3$ & $146.92 \pm 21.4$ & $48.80 \pm 0.89$ & 1.00 \\
\hline \multicolumn{6}{|c|}{ Fractionation using ammonium sulfate } \\
\hline Fraction $1(0-20) \%$ & 27 & $106.65 \pm 30.6$ & $2.65 \pm 1.2$ & $40.19 \pm 3.9$ & 0.82 \\
\hline Fraction $2(20-50) \%$ & 36 & $677.40 \pm 00.0$ & $9.58 \pm 0.3$ & $70.68 \pm 2.5$ & 1.44 \\
\hline Fraction $3(50-80) \%$ & 21 & $17.50 \pm 00.0$ & $1.26 \pm 00.0$ & $13.77 \pm 0.7$ & 0.28 \\
\hline \multicolumn{6}{|l|}{ Dialysis } \\
\hline Dialysis Fraction & 34.60 & $371.95 \pm 130.6$ & $2.73 \pm 1.7$ & $135.92 \pm 16.3$ & 2.78 \\
\hline
\end{tabular}

*Data represented as mean \pm SD $(\mathrm{n}=3)$

\section{Formulation of nanoemulsion}

The proportion of surfactant will affect the form of nanoemulsion. Also, it can inform the surfactant critical point in the nanoemulsion formulation by showing visually stable bases. Based on fig. 1 , nanoemulsions with surfactant concentrations of $15 \%$ and $25 \%$ are unable to stabilize the emulsion so that creaming occurs (phase separation) after $24 \mathrm{~h}$. Meanwhile, a concentration of around 30\% did not visually show stability by phase separation. Phase separation, commonly called creaming, can occur due to the surfactant concentration within the sample being too small, so it is unable to reduce the surface tension optimally. Finally, phase separation occurred due to the differences in density between the oil and water phases. The surfactant concentration of $30 \%(\mathrm{w} / \mathrm{v})$ within a nanoemulsion system is the most stable even after being stored for $15 \mathrm{~d}$. More additions of surfactant concentration would make the charge more negative so that the emulsion would be more stable [13].
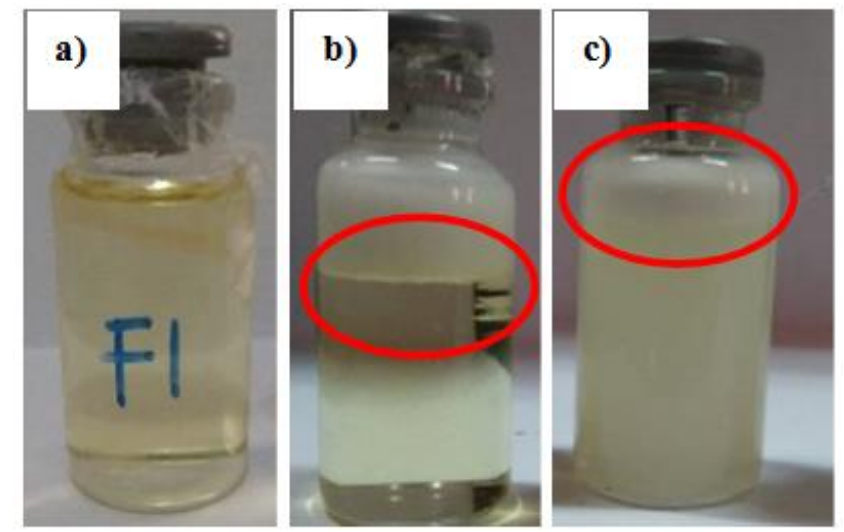

Fig. 1: The observation result of nanoemulsion preparations based on variation of surfactant concentrations. (a) $30 \%$; (b) $25 \%$; (c) $15 \%$

The optimum surfactant concentration in the formulation $30 \%$ $\mathrm{w} / \mathrm{v}$ ) was used for bromelain loading. The bromelain addition in the nanoemulsion occurred after the base had been formed. This process was called the post-loading method. Bromelain is a polar compound that stays on the micelle of the hydrophilic site in nanoemulsion. Nanoemulsion has several advantages, one of which is high hydrophilic drug loading [14]. Besides, in this research, the nanoemulsion was made by the high-energy emulsification method. High-energy emulsification uses high-pressure mechanical energy to break the droplet size down to become smaller. The tools used for this process are a homogenizer and a sonicator. A homogenizer with a high speed of around $3000 \mathrm{rpm}$ and sonication will cause the system temperature to increase. If the temperature system increase, enzyme activity could be decreased, or protein even could be 
denaturized. Hence, the post-loading method is the best way to make bromelain-loaded nanoemulsions.

\section{Characterization of nanoemulsion}

The emulsion type was carried out under an optical microscope (fig. 2 ) at a magnification of $1 \times 0.7$. The resulting image shows that the emulsion type is oil in water $(0 / \mathrm{W})$. The $0 / \mathrm{W}$ type is marked with the methylene blue evenly distributed in nanoemulsion. Meanwhile, if there are only spots, that is confirmed that the nanoemulsion type is water in oil (W/0) [1]. Particle size determination is one of the factors that will affect the absorption of a drug through the skin. The smaller the particle size, the easier the drug will penetrate the skin layer [15]. Based on Table-2, bromelain addition in the nanoemulsion caused the particle size to increase. However, it is still

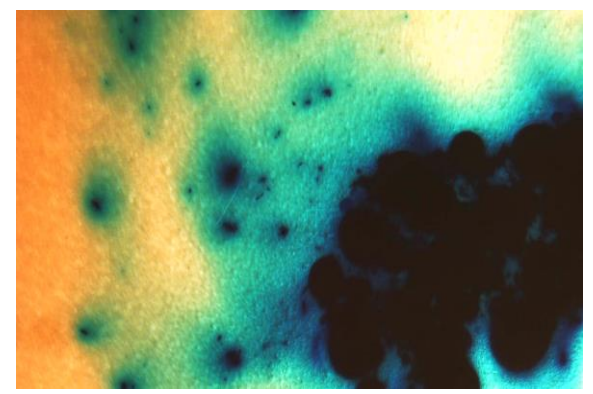

(a) in the allowed range of nanoemulsion characteristics $(<100 \mathrm{~nm})$ [16]. Nanoemulsion with a protein substance can increase its particle size [7], which might be due to the macromolecular protein size. The nanoemulsion stability also could be seen from the polydispersity index value (pdI). The polydispersity index range is between 0 and 1 . If the number closes to 0 , it indicates a homogeneous dispersion, while a value of more than 0.5 indicates high heterogeneity [17]. Based on Table-2, the nanoemulsion value without the addition of bromelain was around 0.099. Meanwhile, the addition of bromelain increased the pdI value to 0.323 . The addition of active substances to the nanoemulsion system causes the homogeneity to decrease. However, the pdI value is still in the allowed range so that the nanoemulsion has stable and homogeneous characteristics.

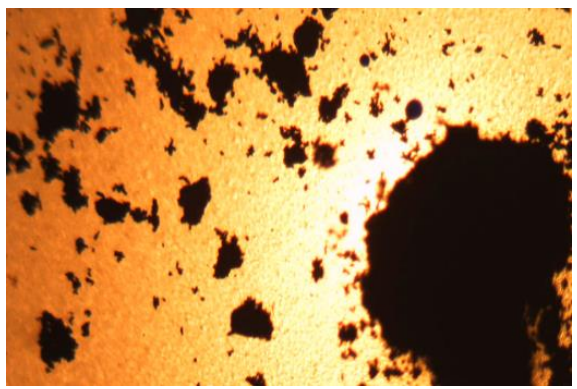

(b)

Fig. 2: (a) Nanoemulsion and methylene blue (o/W), (b) oil and methylene blue (W/0)

Table 2: Results of preparation of globule size measurement

\begin{tabular}{lll}
\hline Sample & Diameter of globule (nm)* $^{*}$ & Polydispersity index $^{*}$ \\
\hline Nanoemulsion base & $16.39 \pm 0.00$ & $0.099 \pm 0.00$ \\
Bromelain in nanoemulsion base & $21.37 \pm 1.8$ & $0.323 \pm 0.049$ \\
\hline
\end{tabular}

$*$ Data represented as mean \pm SD $(n=3)$

Based on fig. 3, nanoemulsion has rheology of plastic flow type. It would not flow until the resulting shear stress produces a specific value. Fig. 3 shows that the value is not constant but can be influenced by the factor of temperature, pressure, and shear rate. Furthermore, the rheogram did not start from a point $(0,0)$. The

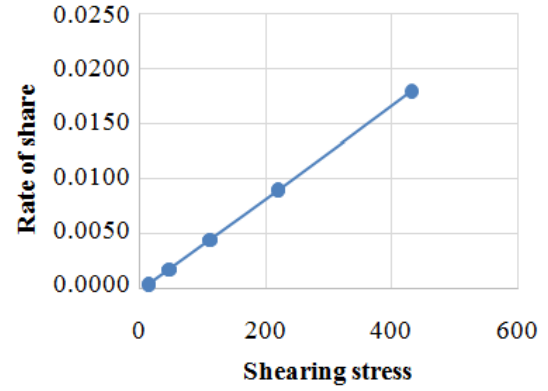

(a) nanoemulsion rheogram with commercial or isolated bromelain shows the change of the rheogram profile was due to the influence of temperature. When the bases were stored at a slightly lower temperature, the viscosity increased, causing the value of the rheogram not to be constant.

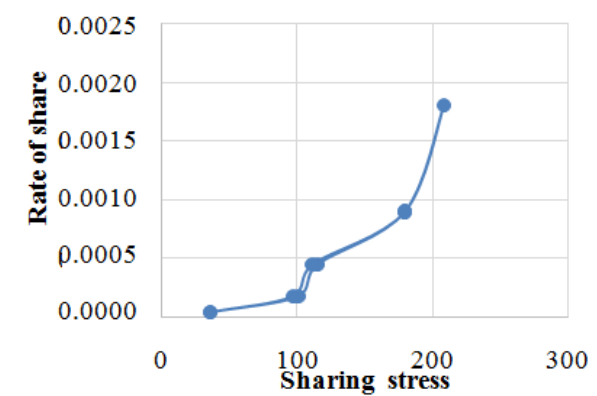

(c)

Fig. 3: Rheogram of a) blank nanoemulsion, b) nanoemulsion with commercial bromelain contained, c) nanoemulsion with bromelain isolated contained 
The viscosity of the nanoemulsion was around $32000 \mathrm{cps}$. This viscosity value is quite high, almost close to the viscosity of gel, whereas the viscosity of a nanoemulsion should be lower than gel. However, this value was acceptable for normal human skin because the viscosity value was fill up the viscosity range of $2000-4000 \mathrm{cps}$ [18]. So it was able to make the active substance diffuse through the matrix base and release the active substance in the skin membrane more easily. The nanoemulsion viscosity is affected by the concentration of its constituent components. Before ethanol addition, this base was quite viscous, similar to vaseline. However, after the addition of ethanol, the form was more like liquid. The addition of ethanol could reduce the viscosity of nanoemulsions.

\section{Stability test of nanoemulsion}

The organoleptic properties of nanoemulsion at different temperatures show that the base remains liquid, transparent yellow, and no phase separation occurred. Although, at low temperatures, the base appears frozen and returns to its normal condition at room temperature. At all temperatures, the $\mathrm{pH}$ tends to decrease gradually (fig. 4), even though the alterations were not significant. A previous study reported that one of the nanoemulsion compositions, namely, Tween 80, can be hydrolyzed to produce fatty acids [19]. The more amount of fatty acid in the emulsion system, the more amount of $\mathrm{H}^{+}$dissociated. This condition has an impact on the lower $\mathrm{pH}$ of the emulsion bases. The nanoemulsion storage at low, high, and room temperature shows that the nanoemulsion $\mathrm{pH}$ is suitable for the transdermal use of normal human skin ( $\mathrm{pH}$ 4.5-6.5).

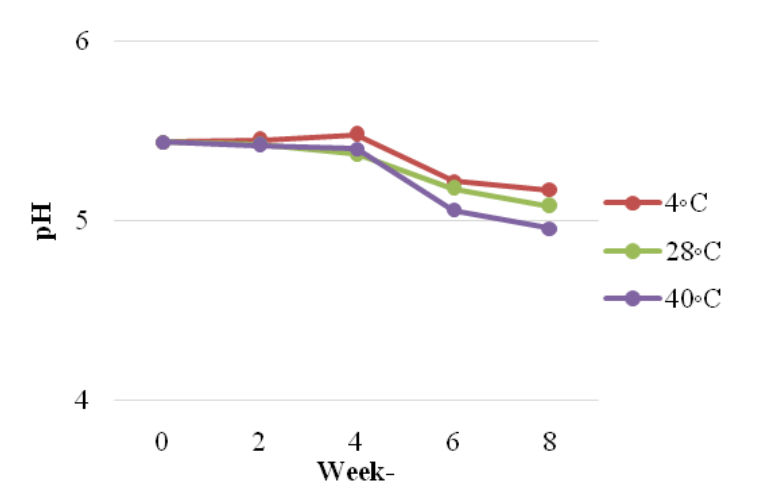

Fig. 4: $\mathrm{pH}$ of nanoemulsion for $8 \mathrm{w}$ at different temperatures. All values are expressed as mean $\pm \operatorname{SD}(n=3)$

Based on the cycling test method, the nanoemulsion formed is stable without phase separation and crystallization of active substances. The alteration of $\mathrm{pH}$ after six cycles did not change significantly, from $5.44 \pm 0.00$ to $5.42 \pm 0.00$, the centrifugal force was given around $3850 \mathrm{rpm}$ for five hours, which is equivalent to the gravity force for a year [1]. Based on the results obtained, the nanoemulsion base showed no phase separation, which means the stability was equivalent for a year.

The assay of enzymatic activity and protein content in nanoemulsion

The enzymatic activity test of bromelain in nanoemulsion compared to free bromelain was performed to observe the stability of proteolytic activity of bromelain within the nanoemulsion base. Measurement of the sample absorption was conducted using a UVVis spectrophotometer.

Based on the data in fig. 5 , the proteolytic activity of the bromelain in the nanoemulsion decrease from 8.50 to $5.00 \mathrm{U} / \mathrm{ml}$. It might be due to the ingredients used in the nanoemulsion. The bromelain is immensely susceptive to its environments, such as temperature and $\mathrm{pH}$ [9]. Therefore, the proper excipients for nanoemulsion are required to maintain the condition and stability of the active substance in the nanoemulsion. The $\mathrm{pH}$ value of nanoemulsion is under bromelain optimum condition (6.0-8.0). The proteolytic activity of bromelain in nanoemulsion is relatively decreased compared to its free bromelain. However, the proteolytic activity of bromelain in the nanoemulsion is stable and maintain at $\mathrm{pH} 5$ for a long period. It might be due to the $\mathrm{pH}$ is similar to the fresh pineapple [20]. This conclusion is also supported by the data results of protein content in the dosage, which also decreased (fig. 6). The addition of nanoemulsion makes dilution at the bromelain protein concentration. The stability of bromelain on dermatological bases has been reported such that enzymatic activity and protein levels decrease after $100 \mathrm{~d}$ of storage [21].

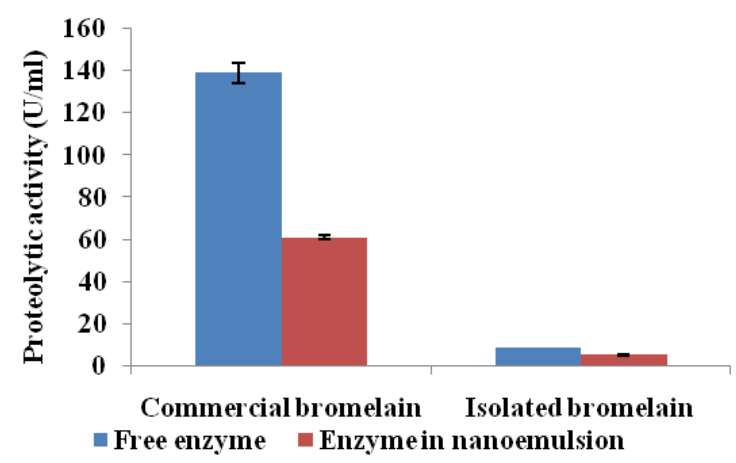

Fig. 5: The proteolytic activity of bromelain $(\mathrm{U} / \mathrm{ml})$. Data represented as mean $\pm S D(n=3)$

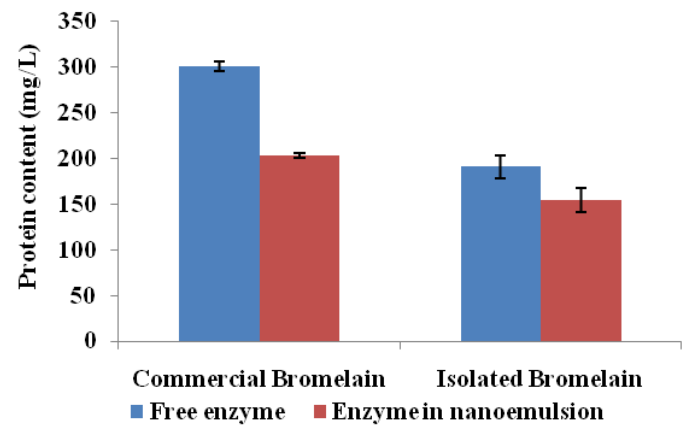

Fig. 6: The protein content of bromelain ( $\mathrm{mg} / \mathrm{l})$. Data represented as mean $\pm \operatorname{SD}(n=3)$

\section{In vitro penetration testing}

Based on fig. 7, commercial bromelain had a better cumulative penetration amount than dialysis fraction due to the protein content of commercial bromelain has been proven to be higher than the dialysis fraction. Moreover, commercial bromelain had a high purity. However, from this information, it could be seen that the dialysis fraction within the nanoemulsion can penetrate through the skin. One of the factors that influence the penetration of an active substance is the excipients that were used. In this study, oleic acid could act as a penetration enhancer. The nanoemulsion can increase the permeation rate because nano-sized droplets can carry drugs across the skin barrier and move into the stratum corneum [22].

The flux graph at each time (fig. 7) shows a high peak at half an hour (minute-30) and then decreased gradually and finally reached horizontal. At minute zero, no bromelain had penetrated. Therefore, the drug gradient concentration between the donor compartment and the receptor compartment became sufficiently large. After minute-thirty, the rate of drug release decreased slowly because the concentration gradient of the drug between the donor compartment and the receptor compartment had started to decline. After all, bromelain has begun to penetrate the receptor compartment. Penetration of the drug from the donor compartment to the receptor compartment is based on the principle of passive diffusion using a drug concentration gradient as a driving force for drug penetration. 


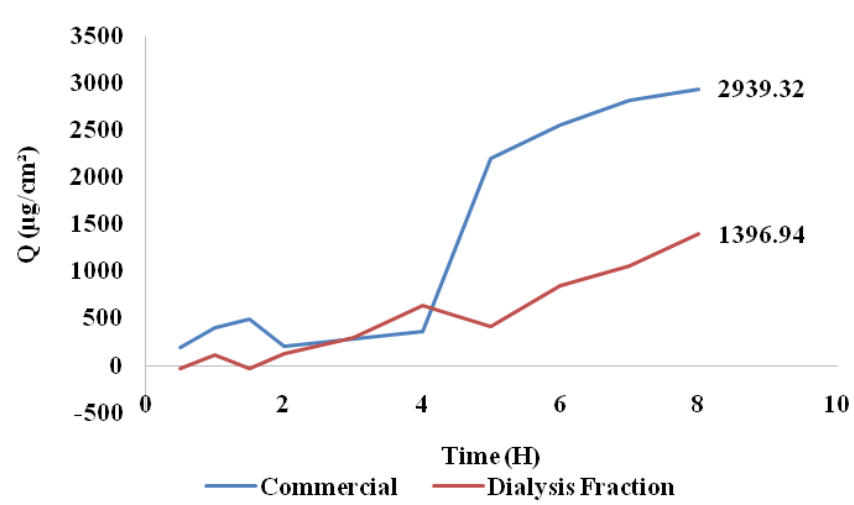

Fig. 7: The profile of cumulative amount of bromelain nanoemulsion

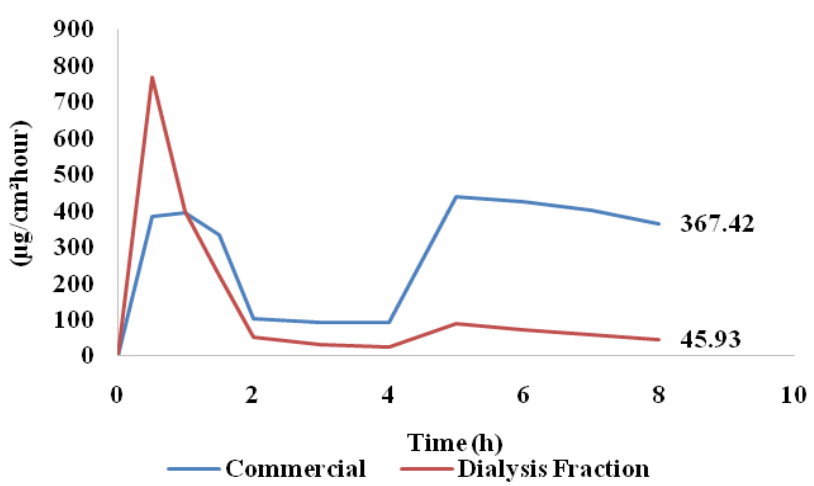

Fig. 8: The profile of penetration velocity (flux) of bromelain nanoemulsion

Based on fig. 8, the flux trend of the isolated bromelain from the first phase showed a higher speed than commercial bromelain. This condition occurs because the isolated bromelain has a more dilute form within the base than commercial bromelain, so that drug diffusion was faster. Besides, commercial bromelain in the first phase is found in the lowest skin layer and has not been completely dissolved in the receptor compartment, so that the diffusion speed is low. However, the penetration rate of commercial enzymes showed a higher value at the next time interval because the enzyme had been dissolved, which was proved by the absorbance increases. The pressure from continuous bromelain released from the donor compartment pushes the bromelain in the skin pores to enter the receptor fluid. When the isolated bromelain decreases or the speed is not significantly changed, it is called the steadystate or saturated condition.

\section{CONCLUSION}

Isolation and purification of bromelain from pineapple core (Ananas comosus [L.] Merr) was successfully done. Precipitation by using a multilevel fractionation method with ammonium sulfate salt showed that fraction 2 (F2) with a saturation level of $20-50 \%$ had the highest specific activity. Subsequent purification using the dialysis method increased the specific activity. The nanoemulsion formed was visually clear, transparent, without any phase separation. The particle size measurement data shows that it is still classified as nanoemulsion. Bromelain within nanoemulsion showed decreased proteolytic activity that associated with protein content decreases. The isolated bromelain within the nanoemulsion formulation was able to penetrate the skin, as proven by the Franz diffusion cell test.

\section{ACKNOWLEDGEMENT}

This research was financially supported by The Directorate of Research and Community Engagement, Universitas Indonesia, for supporting our research through Hibah Publikasi Terindeks Internasional (PUTI) Q3, 2020, NKB-4498/UN2. RST/HKP.05.00/2020.

\section{AUTHORS CONTRIBUTIONS}

All the authors have contributed equally.

\section{CONFLICTS OF INTERESTS}

The authors declare that there were no conflicts of interest.

\section{REFERENCES}

1. Pertiwi I, Setiasih S, Handayani S, Hudiyono S. Bromelain nanoemulsion formulation resulting from partial purification of pineapple core (Ananas comosus [L.] merr) and in vitro testing as antiinflammation. AIP Conf Proc 2020;2243:030017.

2. Novaes LC deL, Jozala AF, Lopes AM, Santos-Ebinuma Vde C, Mazzola PG, Junior AP. Stability, purification, and applications of bromelain: a review. Biotechnol Prog 2016;32:5-13.

3. Pavan R, Jain S, Shraddha, Kumar A. Properties and therapeutic application of bromelain: a review. Biotechnol Res Int 2012;2012:976203.

4. Wu SY, Hu W, Zhang B, Liu S, Wang JM, Wang AM. Bromelain ameliorates the wound microenvironment and improves the healing of firearm wounds. J Surg Res 2012;176:503-9.

5. Muller S, Marz R, Schmolz M, Drewelow B, Eschmann K, Meiser P. Placebo-controlled randomized clinical trial on the immunomodulating activities of low-and high-dose bromelain after oral administration-new evidence on the antiinflammatory mode of action of bromelain. Phyther Res 2013;27:199-204.

6. Ataide JA, Gerios EF, Mazzola PG, Souto EB. Bromelain-loaded nanoparticles: a comprehensive review of the state of the art. Adv Colloid Interface Sci 2018;254:48-55.

7. Suciati $T$, Aliyandi A. Development of transdermal nanoemulsion formulation for simultaneous delivery of protein vaccine and artin-m adjuvant. Int J Pharm Pharm Sci 2014;6:536-46.

8. Gupta PK, Pandit JK, Kumar A, Swaroop P, Gupta S. Pharmaceutical nanotechnology novel nanoemulsion-high energy emulsification preparation, evaluation and application. Pharma Res 2010;3:117-38.

9. Rachmawati H, Sulastri E, Iwo MI, Safitri D, Rahma A. Bromelain encapsulated in self-assembly nanoemulsion exhibit better debriment effect in an animal model of burned skin. J Nano Res 2016;40:158-66. 
10. Setiasih S, Prabowo HA, Budianto E, Hudiyono S. Dissolution profiles of partially purified bromelain from pineapple cores [Ananas comosus (L.) Merr] encapsulated in glutaraldehydecrosslinked chitosan. J Appl Pharm Sci 2018;8:17-24

11. Musfiroh FF, Setiasih S, Handayani S, Hudiyono S, Ilyas NM. In vivo antiplatelet activity aggregation assay of bromelain fractionate by ethanol from extract pineapple core (Ananas comosus [L.] Merr). IOP Conf Ser: Mat Sci Eng 2018;299:012017.

12. Scopes RK. Separation by precipitation. In: Cantor CR, Manor P Ormston K. editors. Protein Precipitation. New York: Springer; 1982. p. 39-66.

13. Chuacharoen T, Prasongsuk S, Sabliov CM. Effect of surfactant concentrations on physicochemical properties and functionality of curcumin nanoemulsions under conditions relevant to commercial utilization. Molecules 2019;24:2744.

14. Tsai MJ, Fu YS, Lin YH, Huang YB, Wu PC. The effect of nanoemulsion as a carrier of a hydrophilic compound for transdermal delivery. PloS One 2014; 9:e102850.

15. Basera K, Bhatt G, Kothiyal P, Gupta P. Nanoemulgel: a novel formulation approach for topical delivery of hydrophobic drugs. World J Pharm Pharm Sci 2015;4:1871-6.
16. El-Hadi AA, Ahmed HM, Zaki RA, Mohsen AM. Enhanced enzymatic activity of Streptomyces griseoplanus L-asparaginase via its incorporation in an oil-based nanocarrier. Int J Appl Pharm 2020;12:203-10.

17. Ferreira CD, Nunes IL. Oil nanoencapsulation: development, application, and incorporation into the food market. Nanoscale Res Lett 2019;14:1-13.

18. Garg A, Aggarwal D, Garg S, Singla AK. Spreading of semisolid formulations an update. Pharm Technol 2002;26:84-105.

19. Kishore RSK, Kiese S, Fischer S, Pappenberger A, Grauschopf U, Mahler HC. The degradation of polysorbates 20 and 80 and its potential impact on the stability of biotherapeutics. Pharm Res 2011;28:1194-210.

20. Novaes LCdeL, Jozala AF, Mazzola PG, Junior AP. The influence of $\mathrm{pH}$, polyethylene glycol and polyacrylic acid on the stability of stem bromelain. Brazilian J Pharm Sci 2014;50:371-80.

21. Bresolin IRAP, Bresolin ITL, Mazzola PG, Tambourgi EB. Incorporation of bromelain into dermatological bases: accelerated stability studies. J Chem Eng 2014;8:270-7.

22. Rachmawati H, Budiputra DK, Mauludin R. Curcumin nanoemulsion for transdermal application: formulation and evaluation. Drug Dev Ind Pharm 2015;41:560-6. 